Arıcı, M. A. ve Dölek, O. (2020). Ortaokul öğrencilerinin yazma özyeterlik algı düzeyleri ile yazma başarımları arasındaki ilişki. Ana Dili Eğitimi Dergisi, 8(4), 1204-1217.

Ana Dili Eğitimi Dergisi
Journal of Mother Tongue Education
www.anadiliegitimi.com
Geliş/Received: 14.08.2020 Kabul/Accepted:18.09.2020
Araştırma Makalesi / Research Paper

\title{
Ortaokul Öğrencilerinin Yazma Özyeterlik Algı Düzeyleri ile Yazma Başarımları Arasındaki ilişki *
}

\author{
Mehmet Ali ARICl ** \\ Onur DÖLEK ${ }^{* * *}$
}

\begin{abstract}
Öz
Bu araştırma, ortaokul öğrencilerinin yazma özyeterlik algı düzeyleri ile yazma başarımları arasındaki ilişkiyi saptamak amacıyla ilişkisel tarama modelinde desenlenmiştir. Araştırmanın çalışma grubunu 5, 6, 7 ve 8. sınıfa devam eden 160 ortaokul öğrencisi oluşturmuştur. Çalışma verilerinin elde edilmesinde "yazma özyeterlik ölçeği" ve öğrencilerin yazılı metinlerinden yararlanılmıştır. Yazılı metinler "kompozisyon değerlendirme ölçeği" ile değerlendirilmiştir. Araştırma verilerinin çözümlenmesinde non-parametrik analiz araçlarından Kruskal-Wallis, Mann Whitney U testleri ve Spearman Korelasyon Katsayısı kullanılmıştır. Araştırmadan elde edilen temel bulgu, yazma başarımı ile yazma özyeterlik algı düzeyi arasında zayıf düzeyde, olumlu ve anlamlı bir ilişkinin olduğudur. Araştırmadan elde edilen diğer bulgular ise yazma özyeterlik algı düzeyinin "cinsiyet" değişkeni açısından anlamlı bir farklılık göstermediği; yazma özyeterlik algı düzeyinin "sınıf" değişkeni açısından anlamlı bir farklılık gösterdiği; sınıflar düzeyinde yazma başarımı ile yazma özyeterliği arasındaki en yüksek ilişkinin 8. sınıfta olduğu yönündedir.
\end{abstract}

Anahtar Kelimeler: Yazma başarımı, yazma özyeterliği, ortaokul öğrencileri, ilişki.

\section{Relationship Between Writing Self-Efficacy Perception Levels and Writing Performance of Secondary School Students}

\begin{abstract}
This research was designed in relational screening model in order to determine the relationship between writing self-efficacy perception level and writing performance of secondary school students. The study group of the research consisted of 160 secondary school students. "Writing self-efficacy scale" and students' written texts were used to obtain study data. Written texts were evaluated with "composition evaluation rubric". Non-parametric analysis tools Kruskal-Wallis, Mann Whitney $U$ and Spearman Correlation Coefficient were used in the analysis of the research data. The main result obtained from the research is that there is a weak, positive and meaningful relationship between writing performance and writing self-efficacy perception levels. Other findings obtained from the study showed that the level of writing self-efficacy perception did not differ significantly in terms of the "gender" variable; the level of writing self-efficacy perception shows a significant difference in terms of "grade" variable; and the highest relationship between writing performance at the grade level and writing self-efficacy is in the 8th grade.

Keywords: Writing performance, writing self-efficacy, secondary school students, relationship.
\end{abstract}

\footnotetext{
* Araştırmanın etik kurulu izni: Gaziantep Üniversitesi Sosyal ve Beşeri Bilimler Etik Kurulu, 24.07.2020, 73628654/604.01.01/35931.

** Arş. Gör., Gaziantep Üniversitesi, Gaziantep Eğitim Fakültesi, Türkçe Eğitimi Ana Bilim Dalı, Gaziantep, arici@gantep.edu.tr, ORCID: 0000-0001-9076-8205

*** Doktora Öğrencisi, Bolu Abant İzzet Baysal Üniversitesi, Lisansüstü Eğitim Enstitüsü, Türkçe Eğitimi Bilim Dalı, Bolu, onur.dolek@hotmail.com, ORCID: 0000-0002-8816-2754
} 


\section{Giriş}

Yazma; duygu, düşünce, tasarı, öngörü ve hayallerin bir dizi bilişsel işlemleme sürecinden sonra kabul görmüş çeşitli sembollerle yazıya aktarılması eylemidir. Bireylerin dili hangi yetkinlikte kullandıklarını ortaya çıkarmaları adına yazma; dili uygulama, sınama ve geliştirme ortamı ve zamanı yaratması bakımından ayrıca önem taşır (Dilidüzgün, 2019). Graham, Harris ve Mason'a (2005) göre yazma karmaşık bir süreçtir ve yazmanın gelişimi büyük ölçüde stratejik davranışlarda, bilgilerde ve motivasyonda ortaya çıkan değişikliklere bağlıdır. Yazmanın genel olarak fiziksel, bilişsel ve duyuşsal olmak üzere üç yönü üzerinde durulur. İnce kas becerilerinin gelişimi, kalem tutma biçimi, görme sağlığı gibi durumlar fiziksel boyutu; düşünme, sözcükleri seçme ve dizme, dilbilgisi kurallarını bilme, metinsellik ölçütlerine uygun metinler oluşturma, özdüzenleme, yansıtma gibi zihin ve buna bağlı gelişen tepkiler bilişsel boyutu; kaygı, tutum, güdü ve özyeterlik gibi belirtiler ise duyuşsal boyutu oluşturan bileşenlerdir. Bu bileşenlerin etkili bir biçimde kullanılabilmesi veya eşgüdümünün sağlanabilmesi için ise belli bir sürece gereksinim duyulmaktadır. Bu doğrultuda yazma alanında yapılan son dönem çalışmalarda (Bayat, 2014; Cahyono ve Astuti, 2019; Dilidüzgün, 2011; Dilidüzgün, 2013; Dölek ve Hamzadayı, 2016; Karatay, 2011; Özdemir ve Özbay, 2016; Sever ve Memiş, 2013; Tompkins, 2005) ürün temelli yaklaşımdan uzaklaşılarak sürece dayalı yazma yaklaşımının öncelendiği görülmektedir. Sürece dayalı yaklaşımla birlikte bireylerin yazmaya dönük denetimlerinin artırılması, böylelikle daha nitelikli yazıı ürünlerin ortaya çıkarılması amaçlanmaktadır.

Yazma süreci boyunca fiziksel, bilişsel ve duyuşsal boyutlara ilişkin ortaya çıkabilecek herhangi bir zayıflık metnin niteliğini olumsuz yönde etkileyebilir. Mekanik açıdan sorunsuz ve bilişsel açıdan zengin bir içeriğe, iyi kurgulanmış bir yapıya ve yaratıcılığa sahip yazılı metinlerin elde edilmesi için sürecin duyuşsal niteliklerinin (kaygı, güdü, tutum ve özyeterlik) denetim altında tutulması gerekir. Öyle ki, nitelikli bir yazılı metin oluşturabilmek için öncelikle bireyin duyuşsal yönden yazma sürecine hazır olması gerekmektedir. Çünkü ancak duyuşsal hazırbulunuşluğu istenen düzeyde olan bireyler yazmanın bilişsel ve mekanik yönüne odaklanabilir. Alanyazındaki çalışmalar (Akar, 2008; Erkan ve Saban, 2013; Süğümlü, Mutlu ve Çinpolat, 2019) yazma kaygısı yüksek, yazmaya karşı olumsuz tutum içerisinde, yazma güdüsü ve yazma özyeterlik algısı düşük olan bireylerin nitelikli bir metin ortaya çıkarmasının pek olanaklı olmadığını göstermektedir.

\section{Yazma Özyeterliği}

Özyeterlik, bireylerin önceden belirlenmiş amaçlara ulaşabilmek için eylem planlarını düzenleme ve yürütme becerilerine ilişkin bireysel yargıları ve inançlarıdır (Bandura, 1977). Ayrıca özyeterlik, bireyin belirli bir düzeyde başarım gösterme yeteneğiyle ilgili inançlarını içeren ve etkinlik, çaba ve performans seçimini etkileyen bilişsel bir yapıdır (Pajares, 1996; Schunk ve Swartz, 1993). Bireylerin özyeterlik algıları, karşılarına çıkan sorunlarla başa çıkıp çıkamayacaklarını belirler. Bir durum ya da olay karşısında kendini gösteren başarabilme inancı bireyi güvende hissettirirken inançsızlık kaçınmaya sürükler (Bandura, 1977). Deci ve Ryan (1987), yüksek özyeterlik algısına sahip olmanın yaratıcılık, esneklik, güçlü problem çözme becerisi, yüksek özgüven ve etkinliklere katılım gibi fiziksel ve bilişsel açıdan birey ve toplum için olumlu sonuçlar sağlayacağını belirtir. Bireylerin bir görevi yerine getirebilme yeteneklerine sahip olduklarına yönelik ikna edici olumlu dönütler (Örn. Bunu yapabilirsin.) almaları özyeterlik algısını yükseltir. Özyeterlik bilgisi bireyin fizyolojik göstergelerini içeren başarımından ve başkaları tarafından sunulan geribildirimlerden elde edilir (Hidi ve Boscolo, 2006: 149).

Davranışlar üzerinde özyeterlik, tek etkili değişken değildir. Başarıya ulaşma sürecinde gerçekleştirilen bir dizi bilişsel ve fiziksel eylemleri beceri, sonuç beklentisi ve süreç çıktılarının algılanan değeri gibi birçok farklı değişken biçimlendirir (Schunk, 1991). Sonuç beklentisi veya eylemin olası sonuçlarına ilişkin inançlar önemlidir çünkü birey olumsuz sonuçlara yol açacağına inandığı eylemi gerçekleştirmek için yeterli düzeyde güdülenemez. Sonuçların algılanan değeri ise bireyin başkalarına göre olası sonuçları ne kadar arzulamasıyla ilgilidir. Yani, sonucun birey açısından taşıdığı önemi gösterir. Yeterli beceriler, olumlu sonuç beklentileri ve kişisel olarak değerli bulunan sonuçlar göz önüne alındığında özyeterliğin birçok davranışın seçimini ve yönünü etkilediği kabul edilmektedir. 
Aile ortamı özyeterliğin geliştirilmesinde en önemli etkenlerden biridir. Aile-çocuk etkileşimi üzerine yapılan çalışmalar ailelerin sürekli olarak yanıt verme, destek olma, güdüleme ve yüreklendirme, akla dayalı gerekçeler sunma ve başarı beklentilerinin çocukların özyeterlik gelişimi ile önemli ölçüde ilişkili olduğunu ortaya koymuştur (Gecas, 1989). Öte yandan toplumbilimsel çalışmalarda özyeterlik üzerine yapılan araştırmaların temelinde özyeterliğin toplum yapısı ile olan ilişkisi yatmaktadır. Toplum yapısının en belirgin yönlerinden olan toplumsal katman veya sınıf, özyeterliğin gelişimi ile ilgilidir. Çünkü toplumsal katmanlar bireylerin eylemlerini farklı biçimlerde değerlendiren düşünsel inanç sistemlerine sahiptir ve bireylerin atılım, katılım, girişkenlik gibi eylemlerinin seyrini etkiler (Gecas ve Schwalbe, 1983). Aile ve sosyal yapının özyeterlik ile ilişkisine koşut olarak Bandura (1977), özyeterlik inançlarının "doğrudan yaşantılar, dolaylı yaşantılar, sözel ikna ve fizyolojik ve duygusal durumlar" olmak üzere dört kaynağından söz etmektedir. Doğrudan yaşantılar bireyin kendi deneyimleri sonucu; dolaylı yaşantılar, benzer konumda olduğu diğer bireylerin yaşantılarını gözlemleme sonucu; sözel ikna, çevresinde bulunan ve hayatında önemli yer edinmiş kimselerin başarabilme inancını aşılaması sonucu; fizyolojik ve duygusal durumlar ise içinde bulunduğu fizyolojik ve duyuşsal sürecin (stres, depresyon, özgüven vb.) etkisi sonucu elde ettiği özyeterlik kaynaklarıdır.

Yukarıda verilen özyeterlik ile ilgili bilgi ve açıklamalardan yola çıkarak yazma özyeterliği, bireyin nitelikli bir yazılı metin oluşturma sürecine ilişkin bilgisine ve becerisine olan inancı ve öngörüsü biçiminde tanımlanabilir. Bir başka deyişle yazma özyeterliği, bireylerin belirli türdeki metinleri üretme yeteneklerine ilişkin algılarını ifade etmektedir (Martinez, Kock ve Cass, 2011; Pajares ve Johnson, 1994; Zimmerman ve Bandura, 1994). Schunk ve Swartz (1993), yazma becerisine yönelik kendisini yetkin hisseden bireylerin yazma yetenekleri konusunda şüpheye sahip bireylerle karşılaştırıldığında daha fazla çaba gösterdikleri ve yazma görevine devam etmeyi yeğlediklerini belirtmişlerdir. Yazma özyeterliği; yazma kaygısı, yazma eylemine verilen önem, özdüzenleme yeterliği, benlik algısı, yazma amaçlarına ulaşma gibi değişkenlerle ilişkilidir ve önbelirleyicilerin ve cinsiyetin yazma başarımı üzerindeki etkisinde aracı rol üstlenir (Pajares ve Valiante, 2006: 162).

İlgi alanı ile ilgili etkinliklerde bulunma (sürece katılım) ve zorluklarla ya da dikkat dağınıklığıyla karşı karşıya kalındığındaki süreci yürütme isteği özyeterliğin önemli iki değişkenidir. Yüksek özyeterlik algıları, daha büyük amaçlar belirlemek, daha etkili öğrenme stratejileri kullanmak ve daha az kaygı duymak gibi birçok olumlu sonuçlarla ilişkilidir (Bong, 2006). Bu bağlamda yazma becerilerine yönelik yüksek özyeterlik algı düzeyi yazmaya ilişkin yaşanan sorunlar karşısında bireyi sürecin içinde tutmayı, bireyin farklı stratejiler kullanmasını, yeni amaçlar belirlemesini sağlar ve aşırı kaygılanmasının önüne geçer. Öte yandan Daniels vd. (2019); Graham, Harris ve Mason (2005) ve Schunk (2003), strateji eğitiminin, akran etkileşiminin, nitelikli geribildirimlerin yazma özyeterliği üzerinde olumlu etkiler oluşturabileceğini belirtir.

Iletişimin birimi metindir ve iletişimsel amaca göre farklı metin türleri ortaya çıkar. Metin olmadan iletişim olmadığı gibi türsüz metin de bulunmaz (Dilidüzgün, 2017). Farklı dil alanlarına ve farklı metin türleri oluşturmaya yönelik özyeterlik algıları ise aynı düzeyde olmayabilir. Bu nedenle bireylerin farklı metin türlerine yönelik yeterlik algılarını belirlemek için farklı yargılar kullanılması gerekir. Örneğin makale yazmaya yönelik özyeterlik algıları ile şiir yazmaya yönelik özyeterlik algıları farklılaşabilir. Bu nedenle iki farklı türden elde edilen sayısal verilerin birbirlerinin yerine kullanılması uygun değildir (Pajares ve Valiante, 2006: 161). Bu nedenle araştırmada öğrencilere açıklayıcı veya görüş bildiren metinler yazdırılmış, özyeterlik ölçeği de bu metin türlerine koşut olarak belirlenmiştir. Böylelikle metin türü ile yazma özyeterliği ölçeğinin maddeleri arasında bir uyum sağlanmaya çalışılmıştır.

Bruning vd. (2013), geliştirmiş oldukları modelde yazma özyeterliğini düşünsel (düşünce üretme), mekanik (kurallar/aktarma) ve özdüzenleme olmak üzere üç temel boyutta incelemişlerdir. Bunlardan ilki olan düşünsel boyut, yazarların düşünce üretebilme ve kavrama yeteneklerine olan inançlarını içerir. Yazma süreci düşünce üretimi olmadan sürdürülemez. Nitekim Flower ve Hayes (1981) yazma modellerinde düşünce üretiminin belirgin bir yere sahip olduğunu vurgular. Bu modellerde düşünce üretimi yazının diğer bölümlerini etkileyen bir süreç olarak gösterilir. Düşünce üretimi, anlambilim alanında kendini gösterir ve düşüncelerden bir içerik oluşturma ve bunları sıralama 
yeteneğine olan inançlarla ilgilidir. İkinci boyut, düşüncelerin yazılı olarak ifade edilmesinde doğru noktalama, büyük harflerin yazımına uyma, uygun cümle yapıları kurma gibi genel kabul görmüş standartlara ilişkin yeteneklere olan inançları kapsar. İlgili alanyazın incelendiğinde bunların yazma mekaniği veya yazma kuralları olarak kabul edildiği görülür. Boyutlardan üçüncüsü özdüzenleme, yazarların birçok boyut ve görev aracılığıyla kendilerini başarılı bir biçimde yönetebileceklerine ilişkin güven duygusunu yansıtır. Düşünce üretimi ve yazma kuralları yazma süreci için önemlidir ancak tek başına yeterli değildir. Özdüzenleme becerileri sadece düşünce üretimi ve yazma stratejilerini kullanmak açısından değil, yazma sürecindeki kaygı, güdü ve tutum gibi duyguları yönetebilme açısından da önem taşımaktadır. Yazma sürecinde sözdizimsel ve anlambilimsel bilgileri düzenleme, yazmaya karşı istekli olma, dikkat dağıtııı şeylerden uzak durma, amaca ulaşılıp ulaşılmadığını denetleme ve yazıyı gözden geçirme gibi stratejiler özdüzenleme sürecinde işe koşulur.

Alanyazın incelendiğinde yazmanın duyuşsal nitelikleri arasında yer alan kaygı, tutum ve güdü gibi etmenleri çeşitli yönlerden inceleyen ve farklı yöntem ve tekniklerin bu bileşenler üzerindeki etkisini sınayan çalışmalar (Alberth, 2018; Arslan, Ilıman ve Aslan, 2019; Baştuğ, 2015; Bayat, 2014; Cheung, 2018; Göçen, 2019; Kırmızı, 2009; McGee, 2019; Ulu, 2018) olduğu görülür. Bunun yanı sıra alanyazında yazma özyeterliğine ilişkin Türkçenin yabancı dil olarak öğretilmesi alanında yapılan (Büyükikiz, 2012; Melanlıoğlu ve Atalay, 2016) çalışmalara; yazma özyeterlik algılarının farklı kademelerde çeşitli değişkenler açısından incelendiği ve yazma özyeterlik algıları üzerinde çeşitli yöntem ve tekniklerin etkisinin sınandığı çalışmalara (Aydın, 2019; Aydın ve Duğan, 2017; Demir, 2013; Korkmaz, 2015; Kuşdemir ve Gülcegül, 2018; Özonat, 2015; Pajares ve Valiante, 1997; Ruegg, 2018; Taş ve Balcı, 2019) rastlanmaktadır. Buna karşın yazma özyeterliğine ilişkin yapılan araştırmalarda farklılık gösteren bulgu, ölçek yeğleyişleri ve sınıf kademelerinden dolayı bu araştırmaya gereksinim duyulmuştur. Bu çalışma aracılığıyla yazma özyeterliği ile yazmanın farklı boyutları arasındaki ilişkiye yönelik elde edilecek bulguların alana katkı sağlayacağı düşünülmektedir. Bu doğrultuda araştırmanın temel problem cümlesi "Öğrencilerin yazma özyeterlik algı düzeyleri ile yazma başarımları arasında anlamlı bir ilişki var mıdır?" biçiminde oluşturulmuştur. Buna bağlı olarak oluşturulan alt problem cümleleri ise şunlardır:

1. Öğrencilerin yazma özyeterlik algı düzeyleri "sınıf" değişkeni açısından anlamlı bir farklılık göstermekte midir?

2. Öğrencilerin yazma özyeterlik algı düzeyleri "cinsiyet" değişkeni açısından anlamlı bir farklılık göstermekte midir?

3. 5, 6, 7 ve 8. sınıflarda yazma başarımı ile yazma özyeterlik algı düzeyi arasında anlamlı bir ilişki var mıdır?

4. Öğrencilerin yazma özyeterlik algı düzeyleri ile yazma becerisinin alt boyutları arasında anlamlı bir ilişki var mıdır? var mıdır?

5. Öğrencilerin yazma başarımları ile yazma özyeterliğinin alt boyutları arasında anlamlı bir ilişki

\section{Araştırmanın Modeli}

\section{Yöntem}

Bu çalışma, ortaokul öğrencilerinin yazma özyeterlik algıları ile yazma başarımları arasındaki ilişkiyi ortaya koymak amacıyla nicel araştırma yöntemlerinden ilişkisel tarama modeliyle desenlenmiştir. illişkisel tarama modeli, iki ya da daha çok değişken arasındaki ilişkinin herhangi bir biçimde değişkenlere müdahale edilmeden incelendiği araştırmalardır (Büyüköztürk vd., 2016: 185). iliş̧kisel tarama modeli gerçek bir neden sonuç ilişkisi vermez. Ancak bu modelde bir değişkendeki durumun bilinmesi, diğerinin kestirilmesine olanak tanır (Karasar, 2006).

\section{Araştırma Grubu}

Araştırmanın çalışma grubunu Gaziantep ilinde bir ortaokula devam eden 103'ü kız, 57'si erkek olmak üzere toplam 160 öğrenci oluşturmaktadır. Cinsiyet ve sınıf düzeyine ilişkin bilgiler Tablo 1'de sunulmuştur: 
Tablo 1.

Cinsiyet ve Sınıf Düzeyine ilişskin Bilgiler

\begin{tabular}{lcc}
\hline & $n$ & $\%$ \\
\hline Cinsiyet & 103 & 64.4 \\
Kiz & 57 & 35.6 \\
Erkek & & \\
Sinıf & 40 & 25 \\
5. Sinıf & 40 & 25 \\
6. Sinıf & 40 & 25 \\
7. Sinıf & 40 & 25 \\
8. Sinıf & & \\
\hline
\end{tabular}

\section{Veri Toplama Araçları}

Araştırmada veri toplama aracı olarak "Yazma Özyeterlik Ölçeği" ve "Kompozisyon Değerlendirme Ölçeği" kullanılmıştır. "Yazma Özyeterlik Ölçeği", Bruning vd. (2013) tarafından geliştirilmiş ve Yılmaz Soylu ve Akkoyunlu (2019) tarafından Türkçeye uyarlanmıştır. Bu ölçek "aktarma", "fikir üretme" ve "özdüzenleme" olmak üzere 3 alt boyut ve tamamı olumlu 13 maddeden oluşmaktadır. Her madde için yazma özyeterlik algısına yönelik olarak öğrencilerden 0-100 (0: sıfır güven; 100: tam güven) arası bir puan vermeleri istenmiştir.

"Kompozisyon Değerlendirme Ölçeği", Konedralı ve Özder (2007) tarafından "buluş", "planlama" ve "anlatım" alt boyutlarında toplam 25 maddeyi içeren $5^{\prime} l i$ likert tipinde geliştirilmiştir.

\section{Verilerin Toplanması}

Araştırma verilerinin toplanması öncesinde ölçeğe ve uygulamaya yönelik ilgili kurum ve araştırmacılardan gerekli izinler alınmıştır. Yazma Özyeterlik Ölçeğinin uygulanacağı sınıflar rastgele belirlenmiş ve uygulama öncesinde öğrenciler ölçek hakkında bilgilendirilmiştir. Ölçeğin doldurulma süresi ortalama 15 dakikadır. Daha sonra Yazma Özyeterlik Ölçeği uygulanan öğrencilerden araştırmacılar tarafından verilen konular arasından, istedikleri türde, yazılı bir metin oluşturmaları istenmiştir. Yazma konuları, ders kitapları gözetilerek oluşturulan konu havuzundan alan uzmanlarının görüşleri doğrultusunda belirlenmiştir. Yazma sürecinde öğrencilere herhangi bir süre kısıtlamasının olmadığı bildirilmiştir.

\section{Verilerin Analizi}

Araştırma verilerinin çözümlenmesinde sürekli değişkenler çarpık olduğundan (normal dağılıma uymadıklarından) non-parametrik testler kullanılmıştır. Bu yüzden kompozisyon değerlendirme ölçeği, yazma özyeterlik ölçeği ve bu ölçeklerin alt boyut puanlarının öğrencilerin sınıflarına göre karşılaştırılmasında Kruskal-Wallis non-parametrik varyans analizine başvurulmuştur. Cinsiyet değişkeni özelinde ise kompozisyon değerlendirme ve yazma özyeterlik ölçeği puanlarının farklılık gösterip göstermediği Mann Whitney $U$ testi ile analiz edilmiştir. Kompozisyon değerlendirme ölçeği toplam puanı ile yazma özyeterlik ölçeği toplam puanı ve alt boyutlarının puanları arasındaki ilişkiye non-parametrik kolerasyon katsayısı olan Spearman Korelasyon Katsayısı uygulanmıştır. İstatistiksel analizler ve hesaplamalar için IBM SPSS Statistics 21.0 (IBM Corp. Released 2012. IBM SPSS Statistics for Windows, Version 21.0. Armonk, NY: IBM Corp.) ve MS-Excel 2007 programları kullanılmıştır. İstatistiksel anlamlılık düzeyi $p<0.05$ olarak kabul edilmiştir.

\section{Geçerlik ve Güvenirlik}

Yazma Özyeterlik Ölçeğinin geçerlik, güvenirlik ve uyarlama çalışmaları Yılmaz Soylu ve Akkoyunlu (2019) tarafından gerçekleştirilmiştir. Bu doğrultuda Yazma Özyeterlik Ölçeğinin dil eşdeğerliğini sağlamak için uzmanlar eşliğinde çeviriler yapılmış ve orijinal ölçeği geliştiren yazarlarla ortak çalışmalar yürütülmüştür. Ölçeğin orijinalinde olduğu gibi Türkçeye uyarlama sürecinde de çalışma grubu olarak ortaokul öğrencileri seçilmiştir. Geçerlik ve güvenirliği belirlemek için yapılan analizler sonucunda ölçeğin bütününe ilişkin iç tutarlık (Cronbach Alfa) değeri .90 olarak saptanmıştır. 
Bunun yanı sıra ölçeğin "aktarma" alt boyutunda iç tutarlığın .82, "fikir üretme" alt boyutunda 87 ve "özdüzenleme" alt boyutunda ise .84 olduğu bulgulanmıştır. Bu bulgular, Türkçeye uyarlanan bu ölçeğin -Tabachnick ve Fidell (2007)'in verilerine göre- yazma özyeterliğini ölçmede dil eşdeğerliği olan geçerli ve güvenilir bir araç olduğunu gösterir.

Kompozisyon Değerlendirme Ölçeğinin bütününe ilişkin Cronbach Alfa güvenirlik katsayısı .80, alt boyutlardan olan buluş .86, planlama .80 ve anlatım .79 olarak hesaplanmıştır. Yazılı metinler bu ölçek aracılığıyla 2 uzman tarafından değerlendirilmiş ve uzmanlar arası tutarlığı belirlemek için Kendall'ın W uyuşum katsayısından yararlanılmıştır. Kendall W istatistiği sonucuna göre W değerinin ,83 olduğu saptanmıştır. Bu değer değerlendirmeciler arasındaki uyumun yüksek olduğunu göstermektedir (Szymanski vd., 1993).

\section{Etik Kurulu İzni}

Bu çalışmada araştırma ve yayın etiğine uyulmuş ve kullanılan ölçeklere ilişkin gerekli izinler alınmıştır.

Kurul adı = Gaziantep Üniversitesi Sosyal ve Beşeri Bilimler Etik Kurulu

Karar tarihi $=24.07 .2020$

Belge sayı numarası $=73628654 / 604.01 .01 / 35931$

\section{Bulgular}

Bu bölümde araştırmanın temel problem cümlesine ve alt problem cümlelerine ilişkin elde edilen bulgular sunulmuştur.

\section{Araştırmanın Temel Problem Cümlesine İlişkin Bulgu}

Tablo 2.

Öğrencilerin Yazma Başarımları ile Yazma Özyeterlik Algı Düzeyleri Spearman ilişki Katsayı Değerleri

\begin{tabular}{lcc}
\hline & Spearman Ilişki Katsayısı & $p$ \\
\hline Yazma Başarımı*Yazma Özyeterlik Algısı & 0.221 & 0.005 \\
\hline
\end{tabular}

Öğrencilerin genel yazma başarımları ile yazma özyeterlik algı düzeyleri arasında zayıf düzeyde doğrusal, pozitif yönlü, istatistiksel olarak anlamlı bir ilişki bulunmaktadır (spearman ilişsi katsayısı $=0.221, p=0.005$ ).

\section{Araştırmanın Birinci Alt Problem Cümlesine illişkin Bulgular}

Tablo 3.

Öğrencilerin Yazma Özyeterlik Algı Düzeylerinin "Sınıf" Değişkenine Göre Kruskal-Wallis Testi Sonucu

\begin{tabular}{|c|c|c|c|c|c|c|c|}
\hline & Sinıf & $\mathrm{N}$ & $\begin{array}{c}\text { Sıra } \\
\text { Ortalaması }\end{array}$ & Ki-kare & $S d(d f)$ & $p$ & Fark \\
\hline \multirow{4}{*}{$\begin{array}{l}\text { Yazma } \\
\text { Özyeterlik } \\
\text { Algısı }\end{array}$} & 5.sınıf & 40 & 90.74 & \multirow{4}{*}{22.640} & \multirow{4}{*}{3} & \multirow{4}{*}{$<0.001$} & \multirow{4}{*}{$\begin{array}{l}5 . \sin I f>8 . \sin \text { If } \\
6 . \sin I f>8 . \sin I f \\
7 . \sin I f>8 . \sin \mathrm{f}\end{array}$} \\
\hline & 6.sınıf & 40 & 96.31 & & & & \\
\hline & 7.sınıf & 40 & 83.61 & & & & \\
\hline & 8.sınıf & 40 & 51.34 & & & & \\
\hline
\end{tabular}

Araştırmaya katılan öğrencilerin yazma özyeterlik algı düzeylerinin sınıf değişkenine göre anlamlı bir fark gösterip göstermediğinin analizi için öncelikle verilerin normallik analizi yapılmış ve özyeterlik sürekli değişkeninin normal dağılmadığı belirlenmiştir $(p<0.05)$. Yapılan Kruskall-Wallis testi sonucunda sınıf gruplarının özyeterlik algı düzeyleri arasında anlamlı bir fark bulunmuştur $(p<0.05)$. Tablo 3'e bakıldığında 5, 6 ve 7. sınıfların yazma özyeterlik algı düzeylerinin 8. sınıf yazma özyeterlik algı düzeylerinden daha yüksek olduğu görülmektedir. 


\section{Araştırmanın İkinci Alt Problem Cümlesine ilişskin Bulgu}

Tablo 4.

Öğrencilerin Yazma Özyeterlik Algı Düzeylerinin "Cinsiyet" Değişkenine Göre Mann-Whitney U Testi Sonucu

\begin{tabular}{llccccc}
\hline & Cinsiyet & $\mathrm{N}$ & $\begin{array}{c}\text { Sıra } \\
\text { Ortalaması }\end{array}$ & $\begin{array}{c}\text { Sıralar } \\
\text { Toplamı }\end{array}$ & U & $\mathrm{p}$ \\
\hline Yazma Özyeterlik & Kız & 103 & 82.24 & 8470.50 & 2756.50 & 0.524 \\
\cline { 2 - 2 } & Erkek & 57 & 77.36 & 4409.50 & & \\
\hline
\end{tabular}

Araştırmaya katılan bireylerin yazma özyeterlik algı düzeylerinin cinsiyete göre anlamlı bir fark gösterip göstermediğinin analizi için öncelikle verilerin normallik analizi yapılmış ve özyeterlik sürekli değişkeninin normal dağılmadığı belirlenmiştir $(p<0.05)$. Yapılan Mann-Whitney $U$ testi sonucunda kız ve erkek grupların yazma özyeterlik algı düzeyleri arasında anlamlı bir fark bulunmamıştır ( $p>0.05)$.

\section{Araştırmanın Üçüncü Alt Problem Cümlesine İlişkin Bulgular}

Tablo 5.

Sınıf Düzeyinde Yazma Başarımı ile Yazma Özyeterlik Algı Düzeyi Spearman Iliş̧ki Katsayı Değerleri

\begin{tabular}{|c|c|c|}
\hline & \multicolumn{2}{|c|}{ Yazma Başarımı*Yazma Özyeterlik Algısı } \\
\hline & Spearman İlişki Katsayısı & $p$ \\
\hline $5 . \sin ı f$ & 0.172 & 0.288 \\
\hline 6.sınıf & 0.390 & 0.013 \\
\hline 7.sınıf & 0.392 & 0.012 \\
\hline 8.sınıf & 0.584 & $<0.001$ \\
\hline
\end{tabular}

5. sınıf öğrencilerinin genel yazma başarımı ile yazma özyeterlik algı düzeyleri arasında istatistiksel olarak anlamlı bir ilişki bulunmamaktadır ( $p>0.05$ ).

6. sınıf öğrencilerinin genel yazma başarımı ile yazma özyeterlik algı düzeyleri arasında zayıf düzeyde, doğrusal, pozitif yönlü bir ilişki vardır. Ayrıca bu ilişki istatistiksel olarak anlamlı saptanmıştır (spearman ilişki katsayısı $=0.390 ; p=0.013$ ).

7. sınıf öğrencilerinin genel yazma başarımı ile yazma özyeterlik algı düzeyleri arasında zayıf düzeyde doğrusal, pozitif yönlü bir ilişki vardır. Ayrıca bu ilişki istatistiksel olarak anlamlı saptanmıştır (spearman ilişki katsayısı $=0.392 ; p=0.012$ ).

8. sınıf öğrencilerinin genel yazma başarımı ile yazma özyeterlik algı düzeyleri arasında orta düzeyde, doğrusal, pozitif yönlü bir ilişki vardır. Ayrıca bu ilişki istatistiksel olarak anlamlı saptanmıştır (spearman ilişki katsayısı $=0.584 ; p<0.001$ ).

\section{Araştırmanın Dördüncü Alt Problem Cümlesine İlişkin Bulgular}

Tablo 6.

Öğrencilerin Yazma Özyeterlik Algı Düzeyleri ile Yazma Becerisi Alt Boyutları Spearman ilişki Katsayı Değerleri

\begin{tabular}{lcc}
\hline & Spearman Illişki Katsayısı & $\mathrm{p}$ \\
\hline Yazma Özyeterlik Algısı * Buluş Alt Boyutu & 0.219 & 0.005 \\
Yazma Özyeterlik Algısı * Planlama Alt Boyutu & 0.170 & 0.031 \\
Yazma Özyeterlik Algısı * Anlatım Alt Boyutu & 0.203 & 0.010 \\
\hline
\end{tabular}


Öğrencilerin yazma özyeterlik algı düzeyleri ile yazma becerisinin "Buluş" alt boyutu arasında zayıf düzeyde, doğrusal, pozitif yönlü, istatistiksel olarak anlamlı bir ilişki bulunmaktadır (spearman ilişki katsayısı $=0.219 ; p=0.005$ ).

Öğrencilerin yazma özyeterlik algı düzeyleri ile yazma becerisinin "Planlama" alt boyutu arasında çok zayıf düzeyde, doğrusal, pozitif yönlü, istatistiksel olarak anlamlı bir ilişki bulunmaktadır (spearman ilişki katsayısı $=0.170 ; p=0.031$ ).

Öğrencilerin yazma özyeterlik algı düzeyleri ile yazma becerisinin "Anlatım" alt boyutu arasında zayıf düzeyde, doğrusal, pozitif yönlü, istatistiksel olarak anlamlı bir ilişki bulunmaktadır (spearman ilişki katsayısı =0.203; $p=0.010$ ).

\section{Araştırmanın Beşinci Alt Problem Cümlesine ilişkin Bulgular}

Tablo 7.

Öğrencilerin Yazma Başarımları ile Yazma Özyeterliği Alt Boyutları Spearman ilişki Katsayı Değerleri

\begin{tabular}{lcc} 
& Spearman Iliş̧i Katsayısı & $\mathrm{p}$ \\
\hline Yazma Başarımı * Aktarma Alt Boyutu & 0.224 & 0.004 \\
Yazma Başarımı * Fikir Üretme Alt Boyutu & 0.218 & 0.006 \\
Yazma Başarımı * Öz Düzenleme Alt Boyutu & 0.165 & 0.037 \\
\hline
\end{tabular}

Öğrencilerin yazma başarımları ile yazma özyeterliğinin "Aktarma" alt boyutu arasında zayıf düzeyde, doğrusal, pozitif yönlü, istatistiksel olarak anlamlı bir ilişki bulunmaktadır (spearman ilişki katsayısı $=0.224 ; p=0.004)$.

Öğrencilerin yazma başarımları ile yazma özyeterliğinin "Fikir Üretme" alt boyutu arasında zayıf düzeyde, doğrusal, pozitif yönlü, istatistiksel olarak anlamlı bir ilişki bulunmaktadır (spearman ilişki katsayısı $=0.218 ; p=0.006)$.

Öğrencilerin yazma başarımları ile yazma özyeterliğinin "Öz Düzenleme" alt boyutu arasında çok zayıf düzeyde, doğrusal, pozitif yönlü, istatistiksel olarak anlamlı bir ilişki bulunmaktadır (spearman ilişki katsayısı $=0.165 ; p=0.037$ ).

\section{Tartışma ve Sonuç}

Öğrencilerin yazma başarımları ile yazma özyeterlik algı düzeyleri arasındaki ilişkiyi saptamak amacıyla yapılan bu araştırmadan elde edilen sonuçlardan biri, yazma başarımı ile yazma özyeterlik algı düzeyi arasında zayıf düzeyde, olumlu ve anlamlı bir ilişkinin olduğudur (spearman ilişki katsayısı $=0.221, p=0.005$ ). Alanyazın incelendiğinde yazma özyeterlik algı düzeyinin yazma başarımını yordayabildiğine ilişkin anlamlı bulgular (Klassen, 2002; Mills, Pajares ve Herron, 2007) olduğu görülür. Nitekim Schunk ve Swartz (1993), öğrencilerinin yazma özyeterliği ve yazma becerileri arasındaki ilişkiyi araştırmış ve özyeterliklerin hem yazma becerisi hem de strateji kullanımı için yordayıcı bir değişken olduğunu bulgulamışlardır. Benzer bir biçimde McCarthy, Meier ve Rinderer (1985) ve Shell, Murphy ve Bruning (1989), yapmış oldukları çalışmalarda yazma özyeterliği ile yazma başarımı arasında anlamlı ve olumlu bir ilişkinin olduğunu saptamışlardır. Graham vd. (2017), yazma özyeterlik düzeyinin yazının niteliğini ve içerik oluşturma bağlamında anlatıların uzunluğunu anlamlı bir biçimde yordadığını, daha yüksek özyeterlik algı düzeyine sahip öğrencilerin daha nitelikli ve daha zengin içeriğe sahip metinler oluşturduklarını ve stratejik yazma davranışları sergileyebilme olasılıklarının daha yüksek olduğunu belirtir. Sanders-Reio vd. (2014) ise yazma özyeterlik düzeyi yüksek olan öğrencilerin nitelikli bir yazılı ürün elde edebilmek için yazma sürecinde diğer öğrencilere oranla daha fazla çaba harcama eğiliminde olduklarını vurgular. Demir (2013), yaratıcı yazma becerileri ile yazma özyeterlik algıları arasında orta düzeyde, anlamlı ve olumlu bir ilişkinin; Taş ve Balcı (2019) ise yazma özyeterlik algısı ile öykü yazma becerisi arasında düşük düzeyde, olumlu ve anlamlı bir ilişkinin olduğunu saptamışlardır. Hidi ve Boscolo (2006: 149), artan özyeterlik algısının streste ve kaygıda azalmayı sağladığını bunun da yazma başarımını olumlu yönde etkilediğini belirtir. 
Yazma başarımı ile yazma özyeterlik algı düzeyi arasındaki ilişkilere sınıf düzeyinde bakıldığında 5. sınıfta anlamlı bir ilişkinin bulunmadığı; 6 ve 7. sınıflarda orta düzeyde, anlamlı ve olumlu ilişkilerin (0.390; 0.392$)$ olduğu ve 8 . sınıfta yine orta düzeyde ancak diğer sınıflara oranla anlamlı, olumlu ve daha yüksek bir ilişkinin (0.584) olduğu görülmektedir. Araştırmadan elde edilen başka bir sonuç da yazma özyeterlik algı düzeyinin "sınıf" değişkeni açısından anlamlı bir farklılık göstermesidir. 8. sınıf öğrencilerinin yazma özyeterlik algı düzeylerinin anlamlı derecede diğer sınıflardan düşük olduğu görülür. 5. sınıf öğrencilerinin yüksek yazma özyeterlik algıları olmasına karşın yazma başarımları aynı düzeyde yüksek değildir. Bandura (1986), yüksek özyeterlik algısına rağmen sürecin olumsuz sonuçlanmasını -5. sınıflarda olduğu gibi- yani bireyin başarısız olmasını yüksek özyeterlik algısının geçici olabileceği ile açıklar. Ayrıca Bandura (1989), sürecin başarıya ulaşmasında gerekli bilgi ve becerilerin yeterli düzeyde olmadığı durumlarda yüksek özyeterlik algısının bir işe yaramayacağını belirtir. Öte yandan bireylerin özyeterliklerine ilişkin üstbilişsel farkındalığı süreç açısından önemlidir. Bu konuda Graham ve Harris (1989), yeteneklerini doğru bir biçimde değerlendirmenin önemli bir üstbilişsel beceri olduğunu, küçük çocukların ve sorunlu öğrencilerin sorunlarının farkında olmada ve performanslarını değerlendirmede zorluk yaşadıkları sonucuna varmışlardır. Benzer bir biçimde Pajares ve Valiante (2006: 166), büyük yaş gruplarının özyeterliklerine dayalı yazma görevlerini yerine getirmede küçük yaş gruplarına göre daha yetenekli olduklarını vurgular. Bunun yanı sıra ortaokulun ilk yılındaki öğrenciler, yazma becerilerinde daha yetkin olan 7 ve 8. sınıflardaki öğrencilere göre daha güçlü bir özyeterlik algılarına sahip olurlar (Pajares ve Valiante, 1999).

Araştırmanın bir diğer sonucu ise yazma özyeterlik algı düzeyinin "cinsiyet" değişkeni açısından anlamlı bir farklılık göstermemesidir. Bu bulguya koşut olarak Özonat (2015), özyeterlik algı düzeyinin yazma psikolojisi boyutunda kız ve erkek öğrenciler arasında herhangi bir farklılı̆ın olmadığını saptamıştır. Benzer bir biçimde Pajares ve Valiante (2006: 165), kızların erkeklerden daha iyi yazma başarımı gösterdiğini ancak kız ve erkek öğrencilerin benzer yazma özyeterlik algılarına sahip olduklarını belirtir. Buna karşın Andrade vd. (2009) ve Taş ve Balcı (2019), kız öğrencilerin yazma özyeterlik algılarının erkek öğrencilerden daha yüksek olduğu sonucuna ulaşmışlardır. Alanyazın incelendiğinde yazma özyeterliği üzerinde cinsiyetin anlamlı bir değişken olup olmadığına ilişkin farklı bulgular olduğu görülmektedir. Gecas (1989), yaş ve aile yaşamından kaynaklı olarak cinsiyetin özyeterlik üzerindeki etkisinin dalgalanma eğiliminde olduğunu; yaşın ilerlemesi ile özyeterlik üzerinde cinsiyetin etkisini yitirdiğini ve bireylerin geçmiş yaşantıları, aile yapısı, toplumsallaşma süreci gibi etkenlerin cinsiyetin özyeterlik üzerindeki etkisinde belirleyici değişkenler olduğunu belirtir.

Yazma başarımı ile yazma özyeterliğinin alt boyutları arasında ve yazma özyeterliği ile yazma başarımının alt boyutları arasında düşük düzeyde, olumlu ve anlamlı bir ilişki olması araştırmadan elde edilen diğer bir sonuçtur. Buna göre yazma başarımının yazma özyeterliğinin aktarma alt boyutu ile en yüksek ilişkide (0.224) olduğu; yazma özyeterliğinin ise yazma başarımının buluş alt boyutu ile en yüksek ilişkide (0.219) olduğu görülmektedir. Bu bağlamda yazının mekaniği ile ilgili becerilere (noktalama ve yazım kuralları, sözcüklerin doğru yazımı, dilbilgisel anlamda doğru cümleler kurabilme vb.) olan özyeterlik algısı ile yazma başarımı arasında daha yüksek bir ilişki olduğu söylenebilir.

Bu araştırmadan ve alanyazındaki diğer çalışmalardan elde edilen yazma özyeterliği ile yazma başarımı arasındaki anlamlı ve olumlu ilişkiye yönelik bulgular, yazma sürecinin başarıya ulaşabilmesinde yazma özyeterlik algısının önemini belirginleştirmektedir. Bu nedenle öğrencilerin yazma özyeterlik algı düzeylerinin istenen düzeyde tutulması gerekir. Alberth (2018) sosyal medya araçlarını yazma eğitimi sürecinde işe koşmanın yazma özyeterliği üzerinde olumlu bir etki sağladığı sonucuna ulaşmıştır. Ayrıca Andrade vd. (2009), sık sık yazma etkinliğine katılmanın yazma özyeterlik algı düzeyini artırdığını bulgulamışlardır. Öte yandan Dilidüzgün (2019) öğrencileri "yazmanın zor olmadığına inandırma" diye bir şeyin söz konusu olmadığını, öğrencilerin dili kullanma düzeylerini ölçecekleri ve geliştirecekleri, düşüncelerini ilişkilendirebilecekleri ve eksik olan bilgilerini ortaya çıkaracakları verimli bir ortam yarattığı konusundaki inançlarının geliştirilmesinin önemli olduğunu vurgulamaktadır. 


\section{Kaynaklar}

Akar, C. (2008). Özyeterlik inancı ve ilk okuma yazmaya etkisi. Uşak Üniversitesi Sosyal Bilimler Dergisi, 1(2), 185-198.

Alberth. (2018). Use of Facebook, students' intrinsic motivation to study writing, writing self-efficacy and writing performance. Technology, Pedagogy and Education, 28(1), 21-36.

Andrade, H. L., Wang, X., Du, Y. ve Akawi, R. L. (2009). Rubric-referenced self-assessment and selfefficacy for writing. The Journal of Educational Research, 102(4), 287-302.

Arslan, A., Ilıman, E. ve Aslan, R. (2019). Sağlık Hizmetleri Meslek Yüksekokulu öğrencilerinin yazma kaygıları ve öz-yeterlik algılarının çeşitli değişkenler açısından incelenmesi. Uluslararası Türk Eğitim Bilimleri Dergisi, 2019(12), 108-127.

Aydın, B. O. ve Duğan, Ö. (2017). Halkla ilişkiler lisans öğrencilerinin yazma öz yeterlik algılarının belirlenmesi üzerine bir çalışma. International Journal of Social Sciences and Education Research, 3(2), 35-49.

Aydın, I. S. (2019). Improvement of preservice Turkish teachers' perceived writing self-efficacy beliefs. Educational Sciences: Theory and Practice, 19(1), 78-94.

Bandura, A. (1977). Self-efficacy: Toward a unifying theory of behavior change. Psychological Review, $84,191-215$.

Bandura, A. (1986). Social foundations of thought and action: A social cognitive theory. Englewood Cliffs, NJ: Prentice-Hall.

Bandura, A. (1989). Social cognitive theory. İçinde R. Vasta (Ed.), Annals of child development. Greenwich, CT: JAI.

Baştuğ, M. (2015). İlkokul dördüncü sınıf öğrencilerinin yazma eğilimi, tutumu ve yazma tutukluğunun yazma başarısı üzerine etkisi. Eğitim ve Bilim, 40(180), 73-88.

Bayat, N. (2014). Sürece dayalı yazma yaklaşımının yazma başarısı ve kaygısı üstündeki etkisi. Kuram ve Uygulamada Eğitim Bilimleri, 14(3), 1123-1141.

Bong, M. (2006). Asking the right question: How confident are you that you could successfully perform these tasks? İçinde F. Pajares ve T. Urdan (Eds.), Self-efficacy beliefs of adolescents (ss. 287303). Greenwich, CT: Information Age.

Bruning, R. H., Dempsey, M., Kauffman, D. F., McKim, C. ve Zumbrunn, S. (2013). Examining dimensions of self-efficacy for writing. Journal of Educational Psychology, 105, 25-38.

Büyükikiz, K. K. (2012). Türkçeyi ikinci dil olarak öğrenen yabancılar için yazma becerisi öz yeterlilik ölçeğinin geliştirilmesi: geçerlilik ve güvenilirlik çalışması. Mustafa Kemal Üniversitesi Sosyal Bilimler Enstitüsü Dergisi, 9(18), 69-80.

Büyüköztürk, Ş., Kılıç Çakmak, E., Akgün, Ö., E., Karadeniz, Ş. ve Demirel F. (2016). Bilimsel araştırma yöntemleri. 21. Baskı, Ankara: Pegem Akademi.

Cahyono, B. Y. ve Astuti, U. P. (2019). Effect of process writing approach combined with video-based mobile learning on indonesian EFL learners' writing skill across creativity levels. International Journal of Instruction, 12(3), 325-340.

Cheung, Y. L. (2018). The effects of writing instructors' motivational strategies on student motivation. Australian Journal of Teacher Education, 43(3), 55-73.

Daniels, S., McCurdy, M., Whitsitt, L., Skinner, C. H., Schwartz-Micheaux, J. ve White, J. (2019). Evaluating the effects of a writing self-efficacy intervention on writing quantity in middle school students. Reading \& Writing Quarterly, 1-17.

Deci, E. L. ve Ryan, R. M. (1987). The support of autonomy and the control of behavior. Journal of Personality and Social Psychology, 53(6), 1024-1037.

Demir, T. (2013). illköğretim öğrencilerinin yaratıcı yazma becerileri ile yazma özyeterlik algısı ilişkisi üzerine bir çalışma. Uluslararası Türkçe Edebiyat Kültür Eğitim (TEKE) Dergisi, 2(1), 84-114.

Dilidüzgün, Ş. (2011). İlköğretim Türkçe derslerinde süreç odaklı yazma çalışmalarının yeri ve önemi. İçinde V. D. Günay, Ö. Fidan, B. Çetin ve F. Yıldız (Ed.), Türkçe Öğretimi Üzerine Çalışmalar (ss. 51-64). İzmir: Dokuz Eylül Üniversitesi Matbaası.

Dilidüzgün, Ş. (2013). The effect of process writing activities on the writing skills of prospective Turkish teachers. Eğitim Araştırmaları-Eurasian Journal of Educational Research, 52, 189-210. 
Dilidüzgün, Ş. (2017). Metindilbilim ve Türkçe öğretimi-uygulamalı bir yaklaşım. Ankara: Anı Yayıncılık. Dilidüzgün, Ş. (2019). Yazma becerisinin önemi. İçinde N. Bayat (Ed.), Yazma ve Eğitimi (ss. 187-223). Ankara: Anı Yayıncılık.

Dölek, O. ve Hamzadayı, E. (2016). Akran etkileşimine dayalı yazma etkinliklerinin 7. sınıf öğrencilerinin yazılı anlatım becerileri üzerindeki etkisi. Turkish Studies, 11(3), 965-980.

Erkan, Y. D. ve Saban, A. I. (2011). Writing performance relative to writing apprehension, self-efficacy in, writing and attitudes towards writing: A correlational study in Turkish tertiary-level EFL. The Asian EFL Journal Quarterly, 13(1), 163-191.

Flower, L. ve Hayes, J. R. (1981). A cognitive process theory of writing. College Composition and Communication, 32(4), 365-387.

Gecas, V. (1989). The social psychology of self-efficacy. Annual Review of Sociology, 15(1), 291-316.

Gecas, V. ve Schwalbe, M. L. (1983). Beyond the looking-glass self: Social structure and efficacy-based self-esteem. Social Psychology Quarterly, 46, 77-88.

Göçen, G. (2019). The effect of creative writing activities on elementary school students' creative writing achievement, writing attitude and motivation. Journal of Language and Linguistic Studies, 15(3), 1032-1044.

Graham, S. ve Harris, K. R. (1989). Improving learning disabled students' skills at composing essays: Self-instructional strategy training. Exceptional Children, 56, 201-214.

Graham, S., Harris, K. R. ve Mason, L. (2005). Improving the writing performance, knowledge, and selfefficacy of struggling young writers: The effects of self-regulated strategy development. Contemporary Educational Psychology, 30(2), 207-241.

Graham, S., Kiuhara, S. A., Harris, K. R. ve Fishman, E. J. (2017). The relationship among strategic writing behavior, writing motivation, and writing performance with young, developing writers. The Elementary School Journal, 188, 1-23.

Hidi, S. ve Boscolo, P. (2006). Motivation and writing. İçinde C. MacArthur, S. Graham ve J. Fitzgerald (Ed.), Handbook of Writing Research (ss. 144-157). New York: Guilford Press.

Karasar, N. (2006). Bilimsel araştırma yöntemi. Ankara: Nobel Yayınları.

Karatay, H. (2011). 4+ 1 planlı yazma ve değerlendirme modelinin öğretmen adaylarının yazılı anlatım tutumlarını ve yazma becerilerini geliştirmeye etkisi. Turkish Studies, 6(3), 1029-1047.

Kırmızı, F. S. (2009). Türkçe dersinde yaratıcı drama yöntemine dayalı yaratıcı yazma çalışmalarının yazmaya yönelik tutuma etkisi. Yaratıcı Drama Dergisi, 4(7), 51-68.

Klassen, R. (2002). Writing in early adolescence: A review of the role of self-efficacy beliefs. Educational Psychology Review, 14, 173-203.

Konedralı, G. ve Özder, H. (2007). Yazılı anlatım becerisinin geliştirilmesinde "Sözlü anlatım destekli ön çalışma" yönteminin etkililiği. Doğu Akdeniz Üniversitesi 1. Uluslararası Türkçe Eğitimi ve Öğretimi Sempozyumu, ss.377-391.

Korkmaz, G. (2015). Yaratıcı yazma yönteminin 6. sınıf öğrencilerinin yazma öz yeterlik algılarına, yazmaya ilişkin tutumlarına ve yazma becerisi akademik başarılarına etkisi. Yayımlanmamış yüksek lisans tezi, Gaziantep Üniversitesi Eğitim Bilimleri Enstitüsü, Gaziantep.

Kuşdemir, Y. ve Gülcegül, S. (2018). İlkokul dördüncü sınıf öğrencilerinin yazma öz yeterlik inançları: Yazabilirim! Journal of International Social Research, 11(59), 779-785.

Martinez, C. T., Kock, N. ve Cass, J. (2011). Pain and pleasure in short essay writing: Factors predicting university students' writing anxiety and writing self-efficacy. Journal of Adoloscent \& Adult Literacy, 54, 351-360.

McCarthy, P., Meier, S. ve Rinderer, R. (1985). Self-efficacy and writing: A different view of selfevaluation. College Composition and Communication, 36, 465-471.

McGee, K. (2019). Reducing writing anxiety by improving self-efficacy beliefs. Learning to Teach, 8(1), 32-38.

Melanlıoğlu, D. ve Atalay, T. D. (2016). Yabancı dil olarak Türkçe öğrenenlerin yazma öz yeterlikleri üzerinde yaratıcı yazma uygulamalarının etkisi. Türkiye Sosyal Araştırmalar Dergisi, 20(3), 697 721. 
Mills, N., Pajares, F. ve Herron, C. (2007). Self-efficacy of college intermediate French students: Relation to achievement and motivation. Language Learning, 57, 417-442.

Özdemir, B. ve Özbay, M. (2016). 6+1 Analitik Yazma ve Değerlendirme Modelinin Türkçe öğretmeni adaylarının yazma becerilerine etkisi. Ana Dili Eğitimi Dergisi, 4(2), 261-276.

Özonat, Z. (2015). Sekizinci sınıf öğrencilerinin yazma öz yeterlik algıları. Erzincan Üniversitesi Sosyal Bilimler Enstitüsü Dergisi, 9(2), 207-220.

Pajares, F. (1996) Self-efficacy beliefs in academic settings. Review of Educational Research, 66, 543578.

Pajares, F. ve Johnson, M. J. (1994). Confidence and competence in writing: The role of writing selfefficacy, outcome expectancy, and apprehension. Research in the Teaching of English, 28, 313331.

Pajares, F. ve Valiante, G. (1997). Influence of self-efficacy on elementary students' writing. The Journal of Educational Research, 90(6), 353-360.

Pajares, F. ve Valiante, G. (1999). Grade level and gender differences in the writing self-beliefs of middle school students. Contemporary Educational Psychology 24, 390-405.

Pajares, F. ve Valiante, G. (2006). Self-efficacy beliefs and motivation in writing development. İçinde C. MacArthur, S. Graham ve J. Fitzgerald (Ed.), Handbook of writing research (ss. 158-170). New York: Guilford Press.

Ruegg, R. (2018). The effect of peer and teacher feedback on changes in EFL students' writing selfefficacy. The Language Learning Journal, 46(2), 87-102.

Sanders-Reio, J., Alexander, P. A., Reio, T. G. ve Newman, I. (2014). Do students' beliefs about writing relate to their writing self-efficacy, apprehension, and performance? Learning and Instruction, 33, 1-11.

Schunk, D. H. (1991). Self-efficacy and academic motivation. Educational Psychologist, 26 (3-4), 207231.

Schunk, D. H. (2003). Self-efficacy for reading and writing: Influence of modeling, goal setting, and selfevaluation. Reading and Writing Quarterly, 19, 159-172.

Schunk, D. H. ve Swartz, C. W. (1993). Goals and progress feedback: Effects on self-efficacy and writing achievement. Contemporary Educational Psychology, 18, 337-354.

Sever, E. ve Memiş, A. (2013). Süreç temelli yazma modellerinin ilkokul dördüncü sınıf öğrencilerinin yazım-noktalama becerisine ve yazma eğilimine etkisi. Karadeniz Sosyal Bilimler Dergisi, 5(9), 243- 259.

Shell, D. F., Murphy, C. C. ve Bruning, R. H. (1989). Self-efficacy and outcome expectancy mechanisms in reading and writing achievement. Journal of Educational Psychology, 81, 91-100.

Sügümlü, Ü., Mutlu, H. H. ve Cinpolat, E. (2019). Relationship between writing motivation levels and writing skills among secondary school students. International Electronic Journal of Elementary Education, 11(5), 487-492.

Szymanski, E. M., Linkowski, D. C., Leahy, M. J., Diamond, E. E. ve Thoreson, R. W. (1993). Human resource development: An examination of perceived training needs of certified rehabilitation counselors. Rehabilitation Counseling Bulletin, 37(2), 163-181.

Tabachnick, B. G. ve Fidell, L. S. (2007). Using multivariate statistics. Boston, MA: Pearson.

Taş, H. ve Balcı, A. (2019). 8. sınıf öğrencilerinin yazma öz yeterlilik algıları ile öykü yazma becerileri üzerine bir araştırma. Okuma Yazma Eğitimi Araştırmaları, 7(1), 51-70.

Tompkins, G. (2005). Language arts: Patterns of practice. 6. Press, Upper Saddle River, NJ: Pearson Prentice Hall.

Ulu, H. (2018). İlkokul dördüncü sınıf öğrencilerinin yazma eğilimleri, tutumları ile yazma başarıları arasındaki ilişki. Kastamonu Eğitim Dergisi, 26(5), 1601-1611.

Yılmaz Soylu, M. ve Akkoyunlu, B. (2019). Yazma öz-yeterlik ölçeğinin Türkçeye uyarlanması. Kastamonu Eğitim Dergisi, 27(5), 2233-2242.

Zimmerman, B. ve Bandura, A. (1994). Impact of self-regulatory influences on writing course attainment. American Educational Research Journal, 31, 845, 862. 


\section{Introduction}

\section{Extended Abstract}

Writing is the act of transferring emotions, thoughts, designs, foresights and dreams into writing with various accepted symbols after a series of cognitive processing processes. According to Graham, Harris and Mason (2005), writing is a complex process, and the development of writing is largely dependent on changes in strategic behavior, knowledge, and affective qualities.

Any deficiencies that may arise regarding the physical, cognitive and affective dimensions throughout the writing process may also adversely affect the quality of the text. Prioritizing the cognitive dimension only in terms of mechanical aspect or content production may not be sufficient alone in obtaining a qualified written product. The affective qualities of the process (anxiety, motivation, attitude and self-efficacy) should also be kept at the desired level in order to obtain written texts with a mechanically problem-free and cognitively rich content, well-constructed structure and creativity. In order to create a high quality written text, the individual must be prepared affectively for the writing process.

Self-efficacy is the individual judgment and beliefs of individuals about their ability to organize and execute action plans to achieve pre-determined goals (Bandura, 1977). In addition, self-efficacy is a cognitive structure that includes beliefs about the individual's ability to perform at a certain level and affects the choice of activity, effort and performance (Pajares, 1996; Schunk \& Swartz, 1993). Individuals' self-efficacy perceptions determine whether they can cope with the problems they face. Belief in succeeding in the face of a situation or event makes the individual feel safe while disbelief continues to avoid (Bandura, 1977). Writing self-efficacy, which is one of the affective qualities, can be defined as the belief and foresight of the individual's knowledge and ability regarding the process of creating a qualified written text. In other words, writing self-efficacy expresses individuals' perceptions about their ability to produce certain types of text (Martinez, Kock \& Cass, 2011; Pajares \& Johnson, 1994; Zimmerman \& Bandura, 1994). It is thought that the findings to be obtained regarding the relationship between writing self-efficacy and different aspects of writing will contribute to the field.

\section{Method}

This study was designed in relational screening model to reveal the relationship between middle school students' writing self-efficacy perceptions and writing performance. Relational screening model is the research in which the relationship between two or more variables is examined without interfering with the variables in any form (Büyüköztürk et al., 2016: 185). The study group of consisted of a total of 160 students, 103 of whom are girls and 57 are boys, who attend a secondary school in Gaziantep.

In data collection on students' perceptions of writing self-efficacy, "Writing Self-Efficacy Scale" was used, which was developped by Bruning et al. (2013) and adapted to Turkish by Yilmaz Soylu and Akkoyunlu (2019). This scale consists of 3 sub-dimensions: "transfer", "generating ideas" and "selfregulation" and 13 items, all of which are positive. "Composition Evaluation Rubric" was used to evaluate written texts obtained from students. This rubric was developped by Konedralı and Özder (2007) as an inventive, planning, and narrative in a 5-point Likert-type with a total of 25 items.

In the analysis of the research data, non-parametric tests were used since the continuous variables were skewed (because they did not fit the normal distribution). Therefore, Kruskal-Wallis non-parametric variance analysis was used to compare the writing scale, self-efficacy scale, and subdimension scores of these scales according to the students' classes. Whether the writing scale and selfefficacy scale scores differ In terms of gender variable was analyzed by Mann Whitney $U$ test. Spearman Correlation Coefficient, which is a non-parametric correlation coefficient, was applied to see the relationship between the writing scale total score and the scores of the self-efficacy scale total score and its sub-dimensions.

\section{Result and Discussion}

One of the results obtained from this study to determine the relationship between students' writing performance and writing self-efficacy perception levels is that there was a weak, positive and 
significant relationship between writing performance and writing self-efficacy perception level ( spearman correlation coefficient $=0.221, p=0.005$ ). When the literature is examined, it can be seen that there are significant findings regarding the level of writing self-efficacy perception (Klassen, 2002; Mills, Pajares and Herron, 2007). As a matter of fact, Schunk and Swartz (1993) investigated the relationship between students' writing self-efficacy and writing skills and found that self-efficacy is a predictive variable for both writing skill and strategy use. Similarly, McCarthy, Meier, and Rinderer (1985) and Shell, Murphy and Bruning (1989) found that there was a significant and positive relationship between writing self-efficacy and writing success. Graham et al. (2017) states that the level of writing self-efficacy significantly predicts the quality of writing and the length of narratives in the context of content creation, that students with higher self-efficacy perception level are more likely to produce texts with higher quality and richer content and are more likely to exhibit strategic writing behaviors.

When the relationship between writing performance and writing self-efficacy perception level is analyzed at the grade level, there was no significant relationship in the 5th grade; in the 6th and 7th grades, it is seen that there are moderate meaningful and positive relationships $(0.390 ; 0.392)$ and in the 8 th grade there was a moderate but higher meaningful and positive relationship $(0.584)$ compared to other grades.

Another result of the study is that the level of writing self-efficacy perception does not differ significantly in terms of the "gender" variable. Another result obtained from the research is that there is a low, positive and significant relationship between the writing success and the sub-dimensions of writing self-efficacy and between the writing self-efficacy and the sub-dimensions of writing performance. According to this, the writing performance is in the highest relation (0.224) with the transfer sub-dimension of writing self-efficacy; and writing self-efficacy has the highest relationship (0.219) with the sub-dimension of the invention. Findings regarding the meaningful and positive relationship between writing self-efficacy and writing achievement obtained from this research and other studies in the literature make the importance of writing self-efficacy perception to be successful in the writing process. In this context, students' self-efficacy perception levels should be followed closely. 